\title{
COXEN Score 14
}

National Cancer Institute

\section{Source}

National Cancer Institute. COXEN Score 14. NCI Thesaurus. Code C128211.

A score of 14 on the COXEN Sensitivity Scale. 